\title{
Small intestinal bacterial overgrowth in systemic sclerosis: a review of the literature
}

\author{
Beata Polkowska-Pruszyńska ${ }^{1}$ - Agnieszka Gerkowicz ${ }^{1}$ Paulina Szczepanik-Kułak ${ }^{1}$. Dorota Krasowska ${ }^{1}$
}

Received: 15 May 2018 / Revised: 27 September 2018 / Accepted: 26 October 2018 / Published online: 31 October 2018

(c) The Author(s) 2018

\begin{abstract}
Systemic sclerosis (SSc) is a chronic, connective tissue disease with an autoimmune pattern characterized by inflammation, fibrosis and microcirculation changes leading to internal organs malfunctions. Recently, the presence of uncharacteristic gastrointestinal symptoms in the course of SSc has been underlined. The possible cause of such clinical presentation is the small intestinal bacterial overgrowth (SIBO). Nevertheless, these manifestations resulting from gastrointestinal tract hypomotility may occur in numerous disease entities. The systematic review of the literature was performed on MEDLINE database using the relevant MeSH terms including all sub-headings. After further investigation, the initial number of 56 records was limited to 7 results. The study analysis showed an increased presence of SIBO in 39\% of patients suffering from SSc. The average SSc duration was longer in SSc patients with coexisting SIBO. SIBO remains a diagnostic and therapeutic challenge and therefore is a significant clinical problem among patients suffering from SSc.
\end{abstract}

Keywords Systemic sclerosis $\cdot$ Small intestinal bacterial overgrowth $\cdot$ SIBO $\cdot$ Diagnosis $\cdot$ Therapy

\section{Introduction}

Systemic sclerosis ( $\mathrm{SSc}$ ) is a chronic, multisystem connective tissue disease of the autoimmune etiology characterized by the microcirculation changes, skin and internal organs fibrosis and the presence of autoantibodies. These particular pathogenetic processes lead to cutaneous lesions as well as systemic complications $[1,3,6,8]$. In genetically predisposed individuals certain factors may cause endothelial cell injury triggering the production of cytokines activating Tand B-lymphocytes. B-lymphocytes produce autoantibodies against gastrointestinal smooth muscles muscarinic receptors altering neuro-muscular junction function. Along with the fibrosis of the gastrointestinal tract provoked by interleukins 4,6 , and 13 produced by Th2 lymphocytes as well as tumor growth factor $\beta$ produced by macrophages these lead to gastrointestinal hypomotility [17]. Approximately $90 \%$ of SSc patients present variously intensified fibrosis in the gastrointestinal tract [3]. Autopsy studies showed muscle atrophy and/or fibrosis in the esophagus, small intestine and large intestine in 74,48 , and $39 \%$, cases, respectively [8]. It is estimated that gastrointestinal involvement is responsible for around $11 \%$ of deaths within SSc patients.

Apart from fibrosis, an important clinical problem is the malfunction of the gastrointestinal tract, including particularly small intestine impairment and affecting around $8-50 \%$ of patients [7, 8, 24]. Usually, patients suffer from bloating, early satiety, periodic diarrhea or food intolerance, most commonly lactose intolerance. Intestinal complications may lead to severe absorption disorders and malnutrition, which significantly aggravate the prognosis of patients [7, 8, 24]. The bowel disorders can be possibly caused by the small intestinal bacterial overgrowth (SIBO). Although the gastrointestinal involvement in systemic sclerosis has been well established, there are few literature data on clinical characteristics of SIBO and its prevalence in SSc patients. The aim of this study was a systematic review of the literature data regarding SIBO presence in patients with systemic sclerosis.

Beata Polkowska-Pruszyńska

polkowska.beata@gmail.com

Chair and Department of Dermatology, Venerology and Paediatric Dermatology, Medical University of Lublin, Lublin, Poland 


\section{SIBO-definition and clinical symptoms}

The human gastrointestinal tract is colonized by numerous microorganisms, which, depending on the localization, vary both quantitatively and qualitatively. The proximal small intestine consists a small number of bacteria, estimated at the maximum of $10^{3} \mathrm{CFU} / \mathrm{ml}$ (colony forming units), whereas in the large intestine the number of bacteria reaches $10^{4} \mathrm{CFU} / \mathrm{ml}[5,11,13,20]$. The maintenance of the normal microbiota environment is very important and every abnormality in this area may lead to serious disorders. One of the possible complications can be the small intestinal bacterial overgrowth, defined as the increase in the number of bacteria to over $10^{5} \mathrm{CFU} / \mathrm{ml}$ or as the presence of atypical flora. Multiple mechanisms are preventing abnormal and extensive bacterial growth. They include gastric acid secretion, bacteriostatic properties of pancreatic juice and bile, the presence of secretive immunoglobulins ( $\operatorname{SIgA}$ ) on the mucous surfaces, vivid intestinal peristalsis and adequately functioning ileocecal valve (Bauchin's valve) [13]. The imbalance of these defence mechanisms, anatomical abnormalities or intestinal motility disorders may lead to SIBO development.

The possible connection between SIBO and SSc seems very interesting. However, the literature data regarding the presence of SIBO in SSc patients have not been widely studied yet and needs further investigation [7]. The impaired gut motility is considered to be one of the leading causes of SIBO in the course of SSc. It may also lead to another SIBO risk factor-the chronic pseudo-obstruction. Moreover, the SSc patients receiving proton pump inhibitors in the therapy of increased gastric acid secretion may also suffer from the disruption of the defence mechanisms preventing the excessive bacterial colonization of small bowel $[5,7,20]$. The symptoms of SIBO including their pathogenesis are depicted in Table $1[5,11,13,20]$.

\section{The prevalence of SIBO in SSc-the systematic review of the literature}

\section{Materials and methods}

The systematic review of the literature was performed on MEDLINE database from 2007 to 2017 complementary to PRISMA protocol (Fig. 1). The inclusion criteria for considering studies for the review based on PICOS structure comprised the population of adult patients diagnosed with systemic sclerosis, performing the hydrogen breathing test as the intervention, preferably the presence of healthy group control, outcomes measured in parts per million in hydrogen breathing test and the included type of studies were retrospective and prospective clinical studies, cohort studies as well as one-case series.

The date of the last search was April 2017. The database was searched using the relevant MeSH terms including all sub-headings. The studies reporting the prevalence of SIBO in SSc patients were identified from the database by utilizing the search terms scleroderma OR systemic sclerosis AND small intestinal bacterial overgrowth OR small intestine bacterial overgrowth OR SIBO OR small bowel bacterial overgrowth OR small intestine overgrowth OR small intestinal overgrowth. The initial search revealed 56 results. After applying additional criteria (English language publications, human studies), the database search revealed 19 records. Five publications describing other than gastrointestinal involvement were excluded. After further investigation, we selected retrospective and prospective clinical studies, cohort studies as well as one-case series study receiving seven results. The studies included in the review are presented in Table $2[8,10,12,19,21$, $23,24]$.

Table 1 The causes of small intestinal bacterial overgrowth symptoms $[5,11,13,20]$

\begin{tabular}{|c|c|}
\hline Symptoms & Pathogenesis \\
\hline $\begin{array}{l}\text { Flatulence } \\
\text { Diarrhea }\end{array}$ & $\begin{array}{l}\text { Bacterial fermentation of carbohydrates with water, short-chain fatty } \\
\text { acids and gases overproduction in intestinal lumen }\end{array}$ \\
\hline $\begin{array}{l}\text { Steatorrhoea } \\
\text { Fat-soluble vitamins deficiency symptoms }(\mathrm{A}, \mathrm{D}, \mathrm{E})\end{array}$ & $\begin{array}{l}\text { Bacterial deconjugation of bile acids leading to insufficient absorption } \\
\text { of fats and fat-soluble vitamins }\end{array}$ \\
\hline Neurological and psychiatric symptoms of malignant anaemia & Bacterial vitamin B12 consumption \\
\hline $\begin{array}{l}\text { Malabsorption syndrome symptoms (weight loss, no weight gain, } \\
\text { malnutrition) }\end{array}$ & Reduced availability of nutrients (proteins, sugars) used by bacteria \\
\hline Hypoproteinemia symptoms (symmetrical, pitting oedema) & $\begin{array}{l}\text { Impaired function of the intestinal barrier causing increased protein } \\
\text { permeability and protein loss }\end{array}$ \\
\hline $\begin{array}{l}\text { Systemic disorders (glomerulonephritis, hepatitis, fatty liver disease, } \\
\text { arthritis, tendonitis) and cutaneous lesions }\end{array}$ & $\begin{array}{l}\text { Increased bacterial counts and intestinal barrier destruction lead to the } \\
\text { development of antigenemia and consequently to the production of } \\
\text { antibodies and the development of type III hypersensitivity reactions }\end{array}$ \\
\hline
\end{tabular}




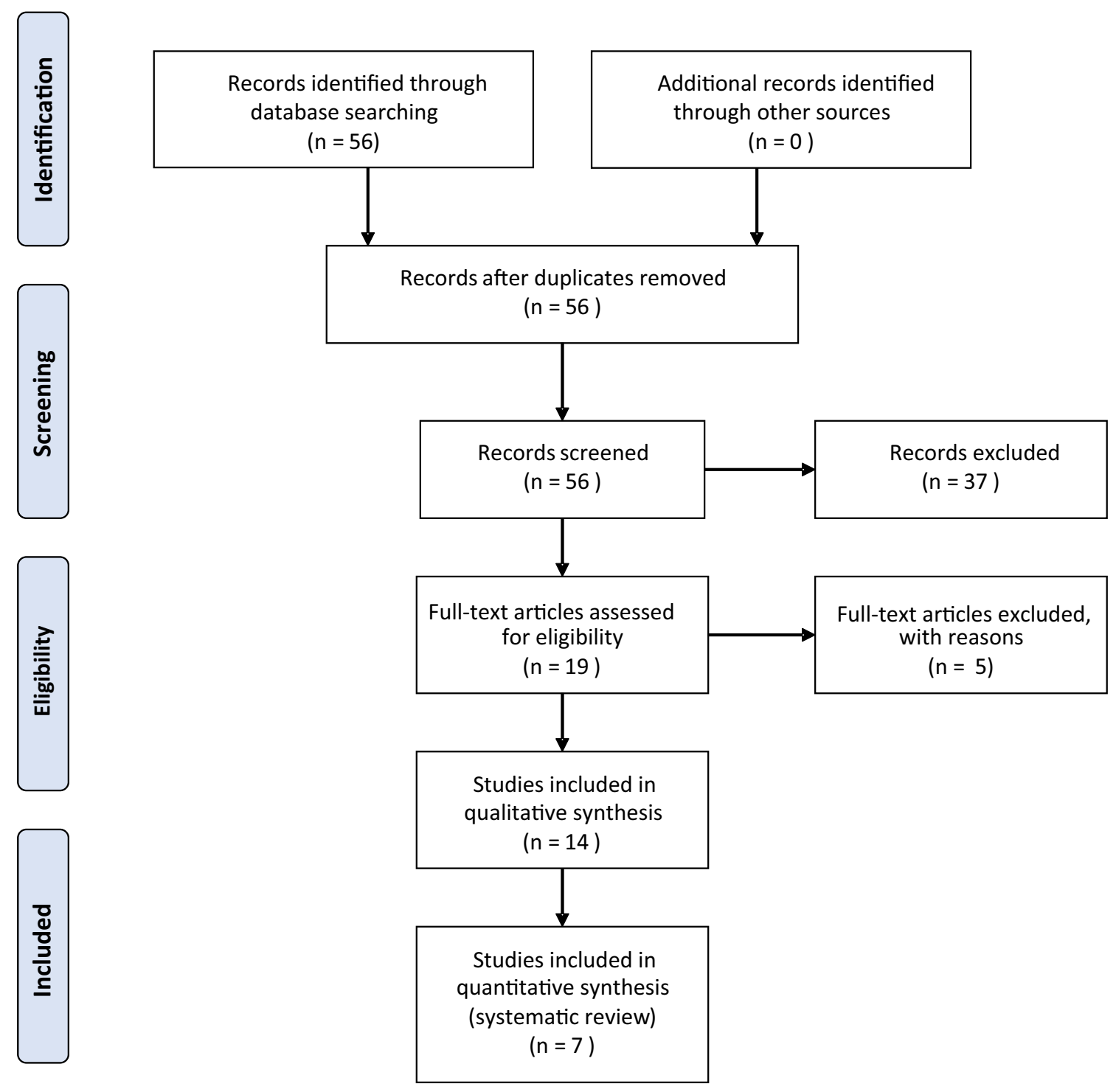

Fig. 1 The systematic review was prepared according to PRISMA statement

\section{Results}

The study analysis showed the presence of SIBO in around $39 \%(18-55 \%)$ patients suffering from SSc $[10,12,18,19$, $21,23,24]$.

The average SSc duration was longer in patients with SIBO diagnosis, on average by 3.7 years longer, while the data on the existence of SIBO depending on the age of the patients remain uncertain. No connection was found between the SIBO occurrence and the subsets of systemic sclerosis (diffuse SSc or limited SSc). The antibodies against topoisomerase I (Scl-70) were less frequent in SIBO patients [24]. Whereas anti-centromere antibodies were present with similar frequency both in the group of patients with SIBO and without SIBO (Table 3) [18, 24].
The laboratory findings in patients with SIBO showed lower median levels of hemoglobin, ferritin, total serum protein, phosphor, calcium, and triglycerides and more elevated erythrocyte sedimentation rate in comparison with the group of patients without SIBO. The observations on serum albumin levels are unclear (Table 3) [22, 23].

Among the SSc patients the most characteristic clinical pattern included symptoms such as diarrhea, constipation, flatulence, abdominal pain, abdominal tenderness, nausea, vomiting, dysuria, tenesmus, dysphagia, reflux, weight loss and early satiety (Table 4) [10, 12, 18, 21, 24]. 


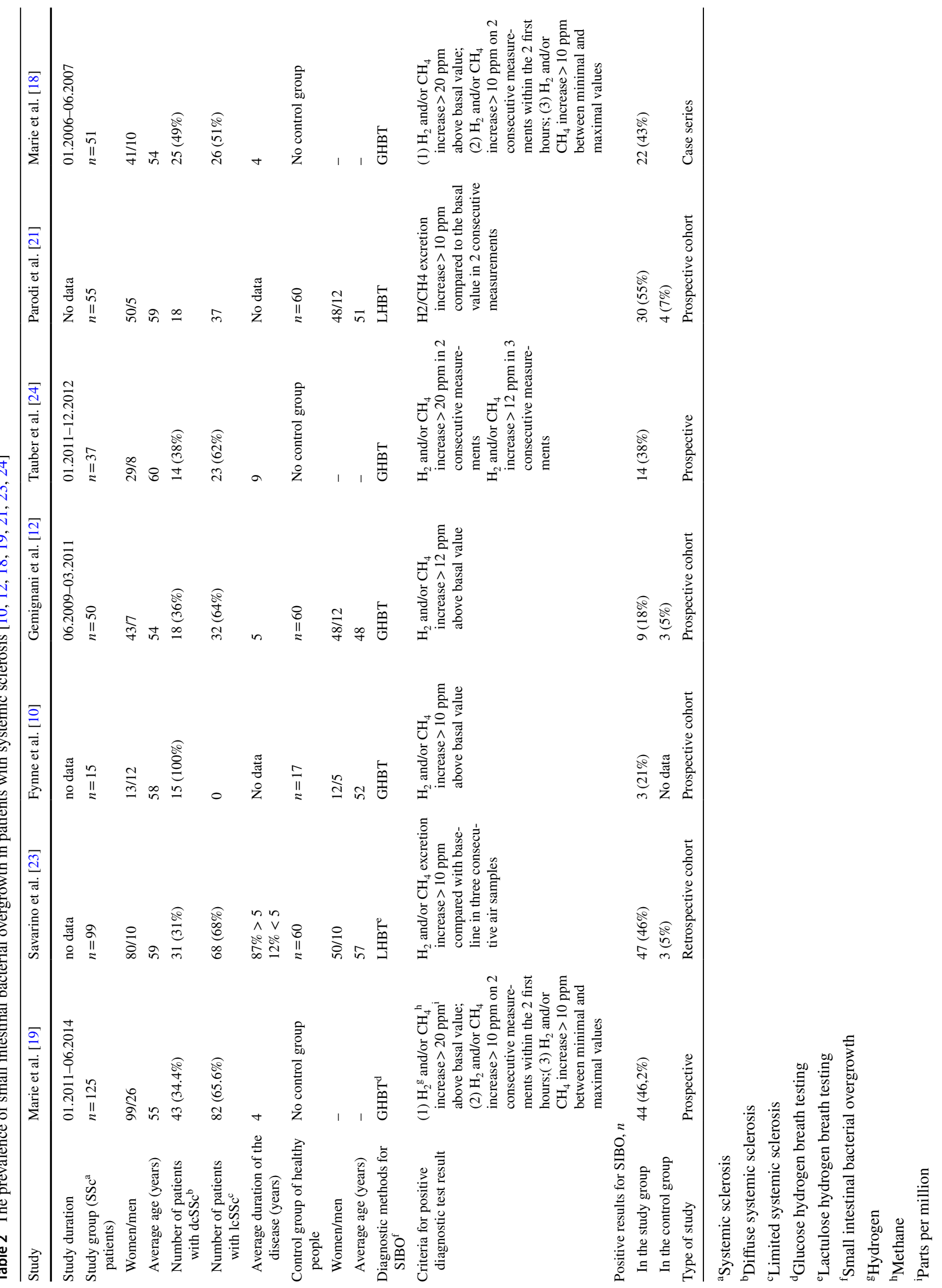


Table 3 The laboratory finding in patients with systemic sclerosis, depending on the occurrence of SIBO syndrome [18, 24]

\begin{tabular}{|c|c|c|c|c|c|c|}
\hline & \multicolumn{3}{|l|}{ Marie et al. [18] } & \multicolumn{3}{|l|}{ Tauber et al. [24] } \\
\hline & $\begin{array}{l}\text { Patients with } \\
\text { SIBO }^{\mathrm{a}}(n=22)\end{array}$ & $\begin{array}{l}\text { Patients without } \\
\text { SIBO }(n=29)\end{array}$ & $p$ value & Patients with SIBO $(n=14)$ & $\begin{array}{l}\text { Patients without } \\
\text { SIBO }(n=23)\end{array}$ & $p$ value \\
\hline \multicolumn{7}{|l|}{ Clinical characteristic } \\
\hline $\mathrm{SSc}^{\mathrm{b}}$ duration (years) & $8.3(1-37)$ & $4.9(1-20)$ & 0.0067 & $11(1-29)$ & $7(3-35)$ & 0.02 \\
\hline Age (years) & $59.5(23-82)$ & $50(34-73)$ & 0.0292 & $61.5(42-80)$ & $59(35-79)$ & 0.5 \\
\hline \multicolumn{7}{|l|}{ SSc subset, $n(\%)$} \\
\hline $\begin{array}{l}\mathrm{dcSSc}^{\mathrm{c}} \\
\operatorname{lcSSC}^{\mathrm{d}}\end{array}$ & $\begin{array}{l}8,(36.4) \\
14,(63.6)\end{array}$ & $\begin{array}{l}17(58.6) \\
12(41.4)\end{array}$ & 0.159 & $\begin{array}{l}5(36) \\
9(64)\end{array}$ & $\begin{array}{l}9(39) \\
14(61)\end{array}$ & 0.9 \\
\hline \multicolumn{7}{|l|}{ Laboratory findings } \\
\hline Anti-Scl70 $\mathrm{Ab}^{\mathrm{e}}$ & $22.7 \%$ & $27.6 \%$ & 0.755 & $7 \%(1)$ & $39 \%(9)$ & 0.04 \\
\hline $\mathrm{ACA} \mathrm{Ab}$ & $40.9 \%$ & $24.9 \%$ & 0.235 & $57 \%(8)$ & $33 \%(7)$ & 0.3 \\
\hline Hemoglobin (g/dl) & $12.2(8.9-14.5)$ & $13.9(10.3-15.5)$ & 0.002 & No data & & \\
\hline Ferritin $(\mu \mathrm{g} / \mathrm{l})$ & $44.5(5-307)$ & $60(2-730)$ & 0.361 & $51.9(10-147)$ & $63.6(10-170)$ & 0.07 \\
\hline Vitamin B12 (pmol/l) & $225(30-748)$ & $288(131-587)$ & 0.133 & $322(166-697)$ & $373(232-488)$ & 0.1 \\
\hline Total serum protein $(\mathrm{g} / \mathrm{l})$ & $65.5(51-77)$ & $69(55-76)$ & 0.66 & No data & & \\
\hline Serum albumin $(\mathrm{g} / \mathrm{l})$ & $39(32-49)$ & $42(30-50)$ & 0.024 & $39.2(35-44)$ & $40(33-45)$ & 0.2 \\
\hline Phosphor (mmol/l) & No data & & & $1.05(0.83-1.35)$ & $1.21(0.94-3.32)$ & 0.03 \\
\hline Calcium (mmol/l) & No data & & & $2.27(2.14-2.41)$ & $2.33(2.22-2.47)$ & 0.03 \\
\hline Triglycerides (mmol/l) & No data & & & $0.96(0.66-1.24)$ & $1.51(0.64-3.32)$ & 0.04 \\
\hline $\operatorname{ESR}^{\mathrm{f}}(\mathrm{mm} / \mathrm{h})$ & $24(4-70)$ & $8(2-78)$ & 0.003 & No data & & \\
\hline
\end{tabular}

${ }^{\text {a }}$ Small intestinal bacterial overgrowth

${ }^{\mathrm{b}}$ Systemic sclerosis

${ }^{\mathrm{c}}$ Diffuse systemic sclerosis

${ }^{\mathrm{d}}$ Limited systemic sclerosis

${ }^{\mathrm{e}}$ Antibodies

${ }^{\mathrm{f}}$ Erythrocyte sedimentation rate

Table 4 Percent of patients with systemic sclerosis presenting selected gastrointestinal symptoms [10, 12, 18, 21]

\begin{tabular}{|c|c|c|c|c|c|c|}
\hline & \multicolumn{2}{|c|}{ Marie et al. [18] } & \multicolumn{2}{|c|}{ Parodi et al. [21] } & \multirow{2}{*}{$\begin{array}{l}\text { Fynne et al. [10] } \\
\text { No group division }\end{array}$} & \multirow{2}{*}{$\begin{array}{l}\text { Gemigani et al. [12] } \\
\text { No group division }\end{array}$} \\
\hline & $\begin{array}{l}\text { Patients with } \\
\operatorname{sibo}^{\mathrm{a}}(\mathrm{n}=22)\end{array}$ & $\begin{array}{l}\text { Patients without } \\
\text { SIBO }(n=29)\end{array}$ & $\begin{array}{l}\text { Patients with } \\
\text { SIBO }(n=30)\end{array}$ & $\begin{array}{l}\text { Patients without } \\
\text { SIBO }(n=25)\end{array}$ & & \\
\hline Diarrhea & $50 \%$ & $10.3 \%$ & $\sim 27 \%$ & $\sim 9 \%$ & $50 \%$ & $22 \%$ \\
\hline $\begin{array}{l}\text { Abdominal pain } \\
\text { Upper } \\
\text { Lower }\end{array}$ & $86.4 \%$ & $31 \%$ & $\begin{array}{l}-30 \% \\
-34 \%\end{array}$ & $\begin{array}{l}-34 \% \\
-29 \%\end{array}$ & $50 \%$ & $\begin{array}{l}-58 \% \\
-70 \%\end{array}$ \\
\hline Bloating & $77.3 \%$ & $44.8 \%$ & $\sim 57 \%$ & $\sim 50 \%$ & $60 \%$ & $62 \%$ \\
\hline Constipation & $59.1 \%$ & $3.4 \%$ & No data & & $33 \%$ & $46 \%$ \\
\hline Nausea & $54.5 \%$ & $37.9 \%$ & $\sim 27 \%$ & $\sim 38 \%$ & & $52 \%$ \\
\hline Vomiting & $18.2 \%$ & $3.4 \%$ & $\sim 4.5 \%$ & $\sim 3 \%$ & No data & $20 \%$ \\
\hline Abdominal tenderness & $54.5 \%$ & $6.9 \%$ & $\sim 54.5 \%$ & $\sim 46 \%$ & No data & $40 \%$ \\
\hline Fever & $18.2 \%$ & 0 & 0 & 0 & No data & $10 \%$ \\
\hline Tenesmus & $13.6 \%$ & 0 & $\sim 50 \%$ & $\sim 46 \%$ & $40 \%$ & $4 \%$ \\
\hline Reflux & No data & & No data & & $93 \%$ & No data \\
\hline Dysphagia & No data & & No data & & $33 \%$ & $44 \%$ \\
\hline Early satiety & No data & & No data & & $25 \%$ & No data \\
\hline
\end{tabular}

${ }^{\text {a }}$ Small intestinal bacterial overgrowth 


\section{Diagnostics}

Despite numerous research, SIBO remains a clinically significant problem. Frequently patients with disorders falling within the spectrum of SIBO symptoms are unsuccessfully diagnosed. The causative factors are the lack of ideal diagnostic test and the insufficient standardization of the available diagnostic procedures [4, 14, 19, 22].

Screening the patients for SIBO should always be considered within patients with non-specific dyspeptic symptoms, motility disorders, gastrointestinal anatomical abnormalities, malnutrition or malabsorption [2, 5, 22]. The clinical manifestations may be a valuable hint; however, because of their low specificity and sensitivity they should not be taken into consideration as a sufficient diagnostic tool. It has been shown that the incidence of dyspeptic symptoms was similar in patients both with positive as well as negative hydrogen breathing test $[16,22]$.

\section{Small intestinal aspiration and culture}

Despite high sensitivity, the culture of aspirated jejunum fluid is only a partially validated diagnostic method [15]. There is no full agreement on the number of bacteria in the small intestine that would define SIBO. However, it is assumed that bacterial count $\geq 10^{3}$ (CFU) $/ \mathrm{ml}$ (colony forming units) is a significant value, and bacterial count $\geq 10^{5} \mathrm{CFU}$ is an equivalent of SIBO diagnosis [22]. Unfortunately, there are some limitations to this method including invasiveness, time-consumption, high technical requirements, the lack of standardization of transport and culture methods [13] as well as the possibility of falsenegative results in case of the endoscopic aspiration of the material only from the proximal part of small bowel [5, 13]. Kaye et al. used this method in SIBO diagnosis in SSc patients with $30 \%$ positive results [9]. At present, in SIBO diagnostics in SSc patients, it is highly recommended to perform additional tests.

\section{Glucose hydrogen breathing test (GHBT) and lactulose hydrogen breathing test (LHBT)}

Significant progress in SIBO diagnostics was Erdogan et al. study, which compared the duodenal aspirate culture and glucose hydrogen breathing test in the group of 139 patients. The microbiological examination revealed SIBO presence in $45 \%$ of patients, whereas the breathing test was positive in $27 \%$ of patients. GHBT had lower sensitivity then duodenal aspiration and culture, whereas its specificity proved to be good. Considering the simplicity, low costs, easy access and non-invasiveness of this method, hydrogen breathing test should be used as a first line diagnostic test [9].

Most commonly used substrates in breathing tests are glucose and lactulose. The breathing tests use the particular ability of bacteria located in the small intestine to metabolize the carbohydrates to hydrogen and methane. These gases are absorbed in the intestinal wall and transported to the lungs where they are eventually excreted by the patient, which allows their detection in exhaled air. Characteristic changes of hydrogen or methane concentration in subsequent breath samples indicate the presence of SIBO. Before the breathing test, the patients should not consume any food for $12 \mathrm{~h}$, for $48 \mathrm{~h}$ maintain low-fiber diet and avoid laxatives and antibiotics. At least for $3 \mathrm{~h}$ after oral glucose or lactulose administration, the measurements of hydrogen and methane concentrations in exhaled air samples are made every $15 \mathrm{~min}$. The results processed by gas chromatography are expressed in ppm (parts per million) [14, 22, 24]. The definite result criteria for both GHBT and LHBT have not been adequately validated yet $[10,12,18,19,21,23,24]$. Hydrogen breathing tests were the most commonly used diagnostic tools in SSc patients in the performed systematic review (Table 2). However, they are difficult to compare with each other as different criteria were used to evaluate positive results.

\section{Evaluation of treatment efficiency}

The clinical symptoms relapse is the measure of effectiveness and clinical response to empirical SIBO treatment. The lack of standardization regarding the type, dose, and duration of antibiotic therapy used puts, however, some serious limitations to this method. Furthermore, the potential adverse effects of empirical antibiotic treatment, the promotion of antibiotic-resistant bacterial strains and the development of pseudomembranous colitis have to be taken into account $[10,12,19]$.

\section{Other diagnostic methods}

Marie et al. evaluated the correlations between SIBO and abnormal calprotectin values in feces in SSc patients. The association of elevated fecal calprotectin levels has been reported in SSc patients with SIBO diagnosed with GBHT. Therefore, fecal calprotectin level can be useful in SIBO assessment in patients suffering from SSc [19]. Other methods include the evaluation of short-chain fatty acids in the small intestine aspiration, unconjugated bile acids in serum, urinary excretion of $p$-aminobenzoic acid or indican, and a 72-h test for fecal fat. Nevertheless, none of these methods are routinely used in clinical practice, and their usefulness has not been clearly defined $[5,14]$. 


\section{SIBO treatment}

SIBO therapy must be comprehensive and targeted to all causes, symptoms and complications [5]. The treatment options include metronidazole, amoxicillin with clavulanic acid, cotrimoxazole, ciprofloxacin, norfloxacin and rifaximin [20]. Therapeutic strategy according to EULAR recommendations involves the oral administration of amoxicillin during the first month $(500 \mathrm{mg} 3 \times / 24 \mathrm{~h})$, ciprofloxacin during the second month $(500 \mathrm{mg} 2 \times / 24 \mathrm{~h})$ and metronidazole during the third month $(500 \mathrm{mg} 3 \times / 24 \mathrm{~h})$. $43 \%$ of SSc patients diagnosed with SIBO showed beneficial effects of such therapy [24]. Currently, high expectations are pinned on rifaximin, nonabsorbable in the digestive tract and presenting bactericidal activity. The effectiveness of rifaximin among SSc patients was estimated at the level of $73.3 \%$. Particularly noteworthy is the complete cessation of diarrhea, the facilitation of other abdominal symptoms and the normalization of lactulose hydrogen breathing tests in all patients after rifaximin administration [21]. Due to the presence of the intestinal motility disorders, it is recommended to avoid the peristalsis reducing drugs such as anticholinergics or opioids in patients with SSc and SIBO [18].

Patients allergic to antibiotics or not responding to optimal doses may use an elemental diet as an alternative. It consists of substances easily digested and absorbed in the proximal small intestine, what prevents the delivery of nutrients to bacteria residing in the distal bowel. The beneficial effects of herbs, prebiotics and probiotics are also suggested [20,22]. Nevertheless, there is no data on the use of such therapy in SSc.

\section{Conclusions}

Small intestinal bacterial overgrowth remains a significant clinical problem among patients suffering from systemic sclerosis. The presence of symptoms such as dyspepsia, flatulence, diarrhea, absorption disorders and malnutrition indicates the necessity of differential diagnosis towards small intestinal bacterial overgrowth.

The SIBO therapy should comprise the treatment of the symptoms and complications, a sufficient and adequate diet and cyclic antibiotic therapy. It is essential to eliminate the risk factors of SIBO, to treat the primary disease, and to neutralize the gastrointestinal motility disorders. Regrettably, hypomotility and fibrosis in the course of $\mathrm{SSc}$ are the final consequences of the pathophysiological processes involving the gastrointestinal tract and in most patients are irreversible. At present, there are no efficient therapies that could reverse the fibrosis of the gastrointestinal tract. The lack of an ideal diagnostic tool underlines the need for the search of new tests and biomarkers that will enable to establish a confident diagnosis of SIBO.

Funding This research received no specific grant from any funding agency in the public, commercial, or not-for-profit sectors.

\section{Compliance with ethical standards}

Conflict of interest The authors declare that there is no conflict of interest.

Ethical approval This article does not contain any studies with human participants or animals performed by any of the authors.

Open Access This article is distributed under the terms of the Creative Commons Attribution 4.0 International License (http://creativeco mmons.org/licenses/by/4.0/), which permits unrestricted use, distribution, and reproduction in any medium, provided you give appropriate credit to the original author(s) and the source, provide a link to the Creative Commons license, and indicate if changes were made.

\section{References}

1. Altman RD, Medsger TA Jr, Bloch DA, Michel BA (1991) Predictors of survival in systemic sclerosis (scleroderma). Arthritis Rheum 34(4):403-413

2. Baker JC, Saad WRJ (2015) Common gastrointestinal symptoms do not predict the results of glucose breath testing in the evaluation of suspected small intestinal bacterial overgrowth. Am J Gastroenterol 110:S1004

3. Bharadwaj S, Tandon P, Gohel T, Corrigan ML, Coughlin KL, Shatnawei A et al (2015) Gastrointestinal manifestations, malnutrition, and role of enteral and parenteral nutrition in patients with scleroderma. J Clin Gastroenterol 49(7):559-564. https://doi. org/10.1097/MCG.0000000000000334

4. Braun-Moscovici Y, Braun M, Khanna D, Balbir-Gurman A, Furst DE (2015) What tests should you use to assess small intestinal bacterial overgrowth in systemic sclerosis? Clin Exp Rheumatol 33(4 Suppl 91):S117-S122

5. Bures J, Cyrany J, Kohoutova D, Förstl M, Rejchrt S, Kvetina J et al (2010) Small intestinal bacterial overgrowth syndrome. World J Gastroenterol 28 16(24):2978-2990. https://doi. org/10.3748/wjg.v16.i24.2978

6. D’Angelo WA, Fries JF, Masi AT, Shulman LE (1969) Pathologic observations in systemic sclerosis (scleroderma). A study of fiftyeight autopsy cases and fifty-eight matched controls. Am J Med 46(3):428-440. https://doi.org/10.1016/0002-9343(69)90044-8

7. Domsic R, Fasanella K, Bielefeldt K (2008) Gastrointestinal manifestations of systemic sclerosis. Dig Dis Sci 53(5):1163-1174. https://doi.org/10.1007/s10620-007-0018-8

8. Ebert EC (2008) Gastric and enteric involvement in progressive system sclerosis. J Clin Gastroenterol 42:5-12. https://doi. org/10.1097/MCG.0b013e318042d625

9. Erdogan A, Rao SS, Gulley D, Jacobs C, Lee YY, Badger C (2015) Small intestinal bacterial overgrowth: duodenal aspiration vs glucose breath test. Neurogastroenterol Motil 27(4):481-489. https://doi.org/10.1111/nmo.12516 
10. Fynne L, Worsøe J, Gregersen T, Schlageter V, Laurberg S, Krogh K (2011) Gastrointestinal transit in patients with systemic sclerosis. Scand J Gastroenterol 46(10):1187-1193. https://doi. org/10.3109/00365521.2011.603158

11. Gabrielli M, D’Angelo G, Di Rienzo T, Scarpellini E, Ojetti V (2013) Diagnosis of small intestinal bacterial overgrowth in the clinical practice. Eur Rev Med Pharmacol Sci 17(Suppl 2):30-35

12. Gemignani L, Savarino V, Ghio M, Parodi A, Zentilin P, de Bortoli $\mathrm{N}$ et al (2013) Lactulose breath test to assess oro-cecal transit delay and estimate esophageal dysmotility in scleroderma patients. Semin Arthritis Rheum 42(5):522-529. https://doi.org/10.1016/j. semarthrit.2012.09.004

13. Grace E, Shaw C, Whelan K, Andreyev HJN (2013) Review article: small intestinal bacterial overgrowth-prevalence, clinical features, current and developing diagnostic tests, and treatment. Aliment Pharmacol Ther 38(7):674-688. https://doi.org/10.1111/ apt.12456

14. Jacobs C, Coss Adame E, Attaluri A, Valestin J, Rao SS (2013) Dysmotility and proton pump inhibitor use are independent risk factors for small intestinal bacterial and/or fungal overgrowth. Aliment Pharmacol Ther 37(11):1103-1111. https://doi.org/10.1111/ apt.12304

15. Kaye SA, Lim SG, Taylor M, Patel S, Gillespie S, Black CM (1995) Small bowel bacterial overgrowth in systemic sclerosis: detection using direct and indirect methods and treatment outcome. Br J Rheumatol 34(3):265-269

16. Khoshini R, Dai SC, Lezcano S, Pimentel M (2008) A systematic review of diagnostic tests for small intestinal bacterial overgrowth. Dig Dis Sci 53(6):1443-1454. https://doi.org/10.1007/ s10620-007-0065-1

17. Kumar S, Singh J, Rattan S, DiMarino AJ, Cohen S, Jimenez SA (2017) Review article: pathogenesis and clinical manifestations of gastrointestinal involvement in systemic sclerosis. Aliment Pharmacol Ther 45(7):883-898. https://doi.org/10.1111/apt.13963

18. Marie I, Ducrotté P, Denis P, Menard JF, Levesque H (2009) Small intestinal bacterial overgrowth in systemic sclerosis. Rheumatology 48(10):1314-1319. https://doi.org/10.1093/rheumatology/ kep226
19. Marie I, Leroi AM, Menard JF, Levesque H, Quillard M, Ducrotte $P(2015)$ Fecal calprotectin in systemic sclerosis and review of the literature. Autoimmun Rev 14(6):547-554. https://doi. org/10.1016/j.autrev.2015.01.018

20. Miazga A, Osiński M, Cichy W, Żaba R (2015) Current views on the etiopathogenesis, clinical manifestation, diagnostics, treatment and correlation with other nosological entities of SIBO. Adv Med Sci 2015 60(1):118-124. https://doi.org/10.1016/j.advms .2014.09.001

21. Parodi A, Sessarego M, Greco A, Bazzica M, Filaci G, Setti M et al (2008) Small intestinal bacterial overgrowth in patients suffering from scleroderma: clinical effectiveness of its eradication. Am J Gastroenterol 103:1257-1262. https://doi.org/10.111 1/j.1572-0241.2007.01758.x

22. Rezaie A, Pimentel M, Rao SS (2016) How to test and treat small intestinal bacterial overgrowth. Curr Gastroenterol Rep 18(2):8. https://doi.org/10.1007/s11894-015-0482-9

23. Savarino E, Mei F, Parodi A, Ghio M, Furnari M, Gentile A et al (2013) Gastrointestinal motility disorder assessment in systemic sclerosis. Rheumatology 52(6):1095-1100. https://doi. org/10.1093/rheumatology/kes429

24. Tauber M, Avouac J, Benahmed A, Barbot L, Coustet B, Kahan A et al (2014) Prevalence and predictors of small intestinal bacterial overgrowth in systemic sclerosis patients with gastrointestinal symptoms. Clin Exp Rheumatol 32(6 Suppl 86):S-S82

\section{Related articles recently published in Archives of Dermatological Research (selected by the journal's editorial staff):}

25. Maguire M, Maguire G (2017) The role of microbiota, and probiotics and prebiotics in skin health. Arch Dermatol Res 309:411-421 